\title{
Effect of Organic Manures and Biofertilizers on Vegetative Growth and Fruit Set of Cape Gooseberry (Physalis peruviana L.)
}

\author{
Shreekant* and D. Ram \\ Department of Horticulture, Narendra Deva University of Agriculture \& Technology, \\ Narendra Nagar (Kumarganj), Faizabad (U.P.) 224229 India \\ *Corresponding author
}

\begin{abstract}
Keywords
Organic manures, Biofertilizers, Vegetative growth, Fruit set

Article Info

Accepted:

15 July 2018

Available Online:

10 August 2018 during the years 2014-15 and 2015-16. The experiment was laid out in Randomized Block Design with 13 treatments and 3 replications. The detail of treatments were as $T_{1}$ - FYM 10 t/ha, $\mathrm{T}_{2}$-Vermicompost 5 t/ha, $\mathrm{T}_{3}$ - Pressmud 10 t/ha, $\mathrm{T}_{4}$ - FYM 10 t/ha + Azotobacter 10 $\mathrm{kg} / \mathrm{ha}, \mathrm{T}_{5^{-}}$Vermicompost $5 \mathrm{t} / \mathrm{ha}+$ Azotobacter $10 \mathrm{~kg} / \mathrm{ha}, \mathrm{T}_{6}$-Pressmud $10 \mathrm{t} / \mathrm{ha}+$ Azotobacter $10 \mathrm{~kg} / \mathrm{ha}, \mathrm{T}_{7}-\mathrm{FYM} 10 \mathrm{t} / \mathrm{ha}+\mathrm{PSB} 10 \mathrm{~kg} / \mathrm{ha}, \mathrm{T}_{8}$-Vermicompost $5 \mathrm{t} / \mathrm{ha}+\mathrm{PSB}$ $10 \mathrm{~kg} / \mathrm{ha}, \mathrm{T}_{9}$ - Pressmud $10 \mathrm{t} / \mathrm{ha}+\mathrm{PSB} 10 \mathrm{~kg} / \mathrm{ha}, \mathrm{T}_{10}-\mathrm{FYM} 10 \mathrm{t} / \mathrm{ha}+$ Azotobacter $10 \mathrm{~kg} / \mathrm{ha}$ + PSB $10 \mathrm{~kg} / \mathrm{ha}, \mathrm{T}_{11^{-}}$Vermicompost 5t/ha + Azotobacter $10 \mathrm{~kg} / \mathrm{ha}+\mathrm{PSB} 10 \mathrm{~kg} / \mathrm{ha}, \mathrm{T}_{12^{-}}$ Pressmud $10 \mathrm{t} / \mathrm{ha}+$ Azotobacter $10 \mathrm{~kg} / \mathrm{ha}+$ PSB $10 \mathrm{~kg} / \mathrm{ha}$ and $\mathrm{T}_{13^{-}}$Control. The maximum plant height at harvest $(107.60 \mathrm{~cm}$ and $111.40 \mathrm{~cm}$.), number of branches per plant at harvest (32.80 and 34.20), days taken to flowering (109.5 and 109.7 days), days taken to fruiting (126.10 and 128.40 days) number of flowers per plant (74.82 and 79.20) and fruit set (93.85 and 94.19 per cent ) were recorded with application of vermicompost $5 \mathrm{t} / \mathrm{ha}+$ Azotobacter $10 \mathrm{~kg} / \mathrm{ha}+\mathrm{PSB} 10 \mathrm{~kg} / \mathrm{ha}\left(\mathrm{T}_{11}\right)$ during years 2014-15 and 2015-16, respectively. However, the minimum values of all characters were recorded under the control.
\end{abstract}

\section{A B S T R A C T}

Present study aimed to evaluate the "Effect of organic manures and biofertilizers on vegetative growth and fruit set of cape gooseberry (Physalis peruviana L.)" was carried out at the Main Experiment Station, Department of Horticulture, Narendra Deva University of Agriculture \& Technology, Narendra Nagar (Kumarganj), Faizabad (U.P.)

\section{Introduction}

The cape gooseberry (Physalis peruviana L.) is annual herbaceous plant belongs to family Solanaceae, bearing globular fruit, each include in inflated calyx, which become pepary on maturity and look like Chinese lantern. It is also commonly called as Poha or poha berry in Hawaii, Golden berry in South
Africa and Rashbhari, Makoi or Tepari in India (Gupta and Roy, 1980; Morton, 1987; Sarangi et al., 1989).

Cape goose berry is a potential underutilized fruit crop which is grown in tropical (as perennial) and subtropical (as annual) regions of the world (Morton, 1987). It is herbaceous in nature and reaches 2 to 3 feet in height 
under favorable growing conditions. The fruit is a berry with smooth, waxy, orange yellow skin (Legge, 1974) and is rich in Vitamin A, B1, B2, and B12 and thus, has potential nutraceutical and pharmaceutical properties (Ramadan and Morsel, 2007).

The name "cape gooseberry" is most probably derived from the name of "Cape of God Hope" of South Africa, where it was commercially grown (Chattopadhyay, 1996). It is originated in Andean highland of Northern South America, in Colombia and reportedly native in Peru and Chile (Legge, 1974) and widely introduced for cultivation into other tropical, sub-tropical and even in temperate areas. It is second highest fresh fruit export in Columbia because of its, nutritional and medicinal attributes. Columbia is the top producer of cape gooseberry world-wide followed by South Africa. In India, it is grown successfully in states like Uttar Pradesh, West Bengal, Madhya Pradesh, Haryana, Punjab, Nillgiri hills and other parts of the country.

The importance of cape gooseberry is not less than any other fruit crops. The edible portion of berry contains $11.5 \%$ carbohydrates, $1.8 \%$ protein, $0.2 \%$ fat, $3.2 \%$ fibre, $0.6 \%$ mineral matter and $49 \mathrm{mg}$. ascorbic acid per $100 \mathrm{~g}$. edible portion of fruit (Khan and Gowder, 1955). The fruit also contains carotene (as vitamin A 2380 IU) (Anonymus, 1969), pectin $0.9 \%$ (Majumder and Bose, 1979) and bioflavonoides (Hayes, 1966). The ripe fruit are taken as such and use in making excellent quality of jelly, sauces and particularly jam, for which it is called as the "Jam fruit of India" (Majumder, 1979).

The management of nutrients through organic manures and biofertilizers can improve physical condition and general health of the soil medium. The organic manures such as FYM, vermicompost and pressmud influence the physico-chemical as well as biological properties of the soil which improve soil fertility, structure, porosity, aeration, drainage and water relation capacity. Biofertilizers help in improving biological activities of desirable microorganisms in the soil and also improve the crop yield and quality of produce. The microorganisms like Azotobacter are considered important not only for their nitrogen fixing efficiency, but also for their ability to produce antibacterial, antifungal compound and growth regulators. Likewise, some phosphate solubilising microbes like PSB are found to be effective in improving phosphorous use efficiency. Moreover, traditional organic manures release the nutrients slowly, hence their effect is exhibited not only on the instant crop but it is also reflected on the performance of the other succeeding crops (Kumar and Srivastava, 2006).

\section{Materials and Methods}

The present investigation entitled "Effect of organic manures and biofertilizers on vegetative growth and fruit set of cape gooseberry (Physalis peruviana L.)" was carried out at the Main Experiment Station, Department of Horticulture, Narendra Deva University of Agriculture \& Technology, Narendra Nagar (Kumarganj), Faizabad (U.P.) India, during the years 2014-15 and 2015-16. The experiment was laid out in Randomized Block Design with 13 treatments and 3 replications. The detail of treatments were as $\mathrm{T}_{1}$ - FYM $10 \mathrm{t} / \mathrm{ha}, \mathrm{T}_{2}$-Vermicompost $5 \mathrm{t} / \mathrm{ha}, \mathrm{T}_{3}-$ Pressmud 10 t/ha, T $4^{-}$FYM 10 t/ha + Azotobacter $10 \mathrm{~kg} / \mathrm{ha}, \mathrm{T}_{5^{-}}$Vermicompost 5 t/ha + Azotobacter $10 \mathrm{~kg} / \mathrm{ha}, \mathrm{T}_{6}$-Pressmud $10 \mathrm{t}$ /ha+ Azotobacter $10 \mathrm{~kg} / \mathrm{ha}, \mathrm{T}_{7}-\mathrm{FYM} 10 \mathrm{t} / \mathrm{ha}+$ PSB $10 \mathrm{~kg} / \mathrm{ha}, \mathrm{T}_{8}$-Vermicompost $5 \mathrm{t} / \mathrm{ha}+\mathrm{PSB}$ $10 \mathrm{~kg} / \mathrm{ha}, \mathrm{T}_{9}$ - Pressmud $10 \mathrm{t} / \mathrm{ha}+$ PSB 10 $\mathrm{kg} / \mathrm{ha}, \mathrm{T}_{10^{-}} \mathrm{FYM} 10 \mathrm{t} / \mathrm{ha}+$ Azotobacter 10 $\mathrm{kg} / \mathrm{ha}+$ PSB $10 \mathrm{~kg} / \mathrm{ha}, \mathrm{T}_{11}$ - Vermicompost $5 \mathrm{t} / \mathrm{ha}+$ Azotobacter $10 \mathrm{~kg} / \mathrm{ha}+\mathrm{PSB} 10 \mathrm{~kg} / \mathrm{ha}$, $\mathrm{T}_{12}$ - Pressmud $10 \mathrm{t} / \mathrm{ha}+$ Azotobacter $10 \mathrm{~kg} / \mathrm{ha}$ 
+ PSB $10 \mathrm{~kg} / \mathrm{ha}$ and $\mathrm{T}_{13^{-}}$Control. The experimental field was ploughed first prepared up to the depth of $20-25 \mathrm{~cm}$ with the help of cultivator. The field was kept open to sun for at least 15 days for destroying the weeds and eggs of insects by repeated ploughing followed by planking to obtain fine tilth. Required area was marked and prepared according to the layout. The organic manures viz., FYM, Vermicompost and Pressmud as well as biofertilizers viz. Azotobacter and PSB were applied as basal dose in their respective plots during last preparation of field and mixed thoroughly in soil. When the seedling attained height of about $20-30 \mathrm{~cm}$, the transplanting was done by khurpi at spacing of $75 \times 75 \mathrm{~cm}$. and just after planting, watering was done by use of watering cane. The vegetative growth such plant height, number of branches per plant at harvest, days taken to flowering, days taken to fruiting, number of flowers per plant and fruit set (per cent) were recorded as following. Plant height at harvest $(\mathrm{cm}$.): The average plant height of 5 tagged plants at harvest stage was measured by using measuring scale from the ground level to the leaf apex of the primary branches. The data expressed as plant height in centimetres. Number of branches per plant at harvest: Average number of branches of 5 marked plants was counted at harvest and their average expressed as number of branches per plant. Days taken to flowering: The period between the dates of planting to first opening (anthesis) was recorded for calculating the days taken to flowering. Days taken to fruiting: The period between the dates of planting and initiation of fruit set was recorded for calculating the days taken to fruiting. Number of flowers per plant: The flowers were counted in tagged plants in each plot at the time of various stage of flower initiation and their average was expressed in number of flowers per plant. Fruit set (per cent): It was calculated as number of fruits set, divided by number of flower appeared and expressed in percentage.

$$
\text { Fruit set }(\%)=\frac{\text { Number of fruits set }}{\text { Number of flowers appeared }} \times 100
$$

The statistical analysis of data was carried out as per method prescribed by Panse and Sukhatme (1985).

\section{Results and Discussion}

The maximum plant height $(107.60 \mathrm{~cm}$ and $111.40 \mathrm{~cm}$ ) were recorded with application of vermicompost $5 \mathrm{t} / \mathrm{ha}+$ Azotobacter $10 \mathrm{~kg} / \mathrm{ha}+$ PSB $10 \mathrm{~kg} / \mathrm{ha}\left(\mathrm{T}_{11}\right)$ during years $2014-15$ and 2015-16, respectively which was at par with pressmud $10 \mathrm{t} / \mathrm{ha}+$ Azotobacter $10 \mathrm{~kg} / \mathrm{ha}+$ PSB $10 \mathrm{~kg} / \mathrm{ha}\left(\mathrm{T}_{12}\right)$ during both years 2014-15 and 2015-16. Minimum plant height 80.20 and $77.90 \mathrm{~cm})$ was recorded in control $\left(\mathrm{T}_{13}\right)$ during both years, respectively. The increase in average plant height may be attributed to the fact that nitrogen in the vermicompost is building block of protein and is the main constituent of protoplasm in plant. Thus accelerates synthesis of amino acids which might have resulted increase in plant height of cape gooseberry plant. Further Azotobacter and PSB might have facilitated physiological process of plant included indirectly activity cell division and cell elongation of plants.

Another reason might be due to application of biofertilizers such as Azotobacter and PSB help to increase the biological nitrogen fixation and phosphorus which is required for strong vegetative growth. The other reason for increased for plant height might be due to production of more chlorophyll content with inoculation of nitrogen fixers (Table 1). 
Table.1 Effect of organic manures and biofertilizers on vegetative growth and fruit set of cape gooseberry (Physalis peruviana L.)

\begin{tabular}{|c|c|c|c|c|c|c|c|c|c|c|c|c|}
\hline \multirow[t]{2}{*}{ Treatments } & \multicolumn{2}{|c|}{ Plant height $(\mathrm{cm})$} & \multicolumn{2}{|c|}{$\begin{array}{l}\text { Number of } \\
\text { branches per } \\
\text { plant }\end{array}$} & \multicolumn{2}{|c|}{$\begin{array}{l}\text { Days taken to } \\
\text { flowering }\end{array}$} & \multicolumn{2}{|c|}{$\begin{array}{l}\text { Days taken to } \\
\text { fruiting }\end{array}$} & \multicolumn{2}{|c|}{$\begin{array}{l}\text { Number of } \\
\text { flowers per plant }\end{array}$} & \multicolumn{2}{|c|}{ Fruit set (\%) } \\
\hline & 2014-15 & 2015-16 & 2014-15 & 2015-16 & 2014-15 & 2015-16 & 2014-15 & 2015-16 & 2014-15 & 2015-16 & 2014-15 & 2015-16 \\
\hline$T_{1}:$ FYM 10 t/ha & 91.20 & 92.40 & 28.45 & 28.66 & 106.80 & 107.00 & 118.52 & 119.10 & 56.40 & 57.60 & 89.39 & 89.51 \\
\hline $\mathrm{T}_{2}:$ Vermicompost $5 \mathrm{t} / \mathrm{ha}$ & 93.40 & 95.20 & 29.19 & 29.45 & 107.90 & 108.40 & 120.80 & 121.60 & 59.74 & 61.54 & 90.12 & 90.28 \\
\hline$T_{3}: \quad$ Pressmud 10 t/ha & 92.60 & 94.00 & 28.52 & 28.76 & 107.40 & 107.70 & 119.10 & 119.70 & 58.82 & 60.32 & 89.45 & 89.85 \\
\hline $\mathrm{T}_{4}:$ FYM $10 \mathrm{t} / \mathrm{ha}+$ Azotobacter $10 \mathrm{~kg} / \mathrm{ha}$ & 95.80 & 97.20 & 30.22 & 30.44 & 107.80 & 109.50 & 120.99 & 121.89 & 62.91 & 64.81 & 90.28 & 90.46 \\
\hline $\mathrm{T}_{5}:$ Vermicompost $5 \mathrm{t} / \mathrm{ha}+$ Azotobacter $10 \mathrm{~kg} / \mathrm{ha}$ & 99.00 & 100.50 & 30.68 & 30.95 & 108.20 & 109.60 & 122.40 & 123.70 & 65.60 & 68.10 & 90.70 & 90.91 \\
\hline$T_{6}:$ Pressmud 10 t/ha + Azotobacter $10 \mathrm{~kg} / \mathrm{ha}$ & 98.10 & 99.70 & 30.46 & 30.72 & 108.70 & 109.60 & 121.60 & 122.60 & 63.55 & 65.85 & 90.40 & 90.58 \\
\hline $\mathrm{T}_{7}:$ FYM $10 \mathrm{t} / \mathrm{ha}+$ PSB $10 \mathrm{~kg} / \mathrm{ha}$ & 100.50 & 102.60 & 30.92 & 31.20 & 108.90 & 109.50 & 123.50 & 124.90 & 66.78 & 69.18 & 91.49 & 91.73 \\
\hline $\mathrm{T}_{8}:$ Vermicompost $5 \mathrm{t} / \mathrm{ha}+$ PSB $10 \mathrm{~kg} / \mathrm{ha}$ & 102.60 & 105.40 & 31.84 & 32.16 & 108.80 & 109.60 & 124.50 & 126.30 & 70.24 & 73.64 & 91.87 & 92.15 \\
\hline $\mathrm{T}_{9}:$ Pressmud $10 \mathrm{t} / \mathrm{ha}+$ PSB $10 \mathrm{~kg} / \mathrm{ha}$ & 101.90 & 104.50 & 31.28 & 31.58 & 108.90 & 109.30 & 123.70 & 125.40 & 69.18 & 71.98 & 91.76 & 92.05 \\
\hline $\begin{array}{l}T_{10}: \text { FYM } 10 \mathrm{t} / \mathrm{ha}+\text { Azotobacter } 10 \mathrm{~kg} / \mathrm{ha}+\text { PSB } \\
10 \mathrm{~kg} / \mathrm{ha}\end{array}$ & 104.80 & 108.10 & 31.95 & 32.58 & 109.30 & 100.40 & 124.90 & 126.70 & 72.26 & 75.78 & 92.51 & 92.82 \\
\hline $\begin{array}{l}T_{11}: \text { Vermicompost } 5 \mathrm{t} / \mathrm{h}+\text { Azotobacter } 10 \mathrm{~kg} / \mathrm{ha}+ \\
\text { PSB } 10 \mathrm{~kg} / \mathrm{ha}\end{array}$ & 107.60 & 111.40 & 32.80 & 34.20 & 109.50 & 109.70 & 126.10 & 128.40 & 74.82 & 79.20 & 93.85 & 94.19 \\
\hline $\begin{array}{l}T_{12}: \text { Pressmud } 10 \mathrm{t} / \mathrm{ha}+\text { Azotobacter } 10 \mathrm{~kg} / \mathrm{ha}+ \\
\text { PSB } 10 \mathrm{~kg} / \mathrm{ha}\end{array}$ & 105.60 & 109.40 & 32.68 & 33.78 & 109.40 & 109.30 & 125.40 & 127.40 & 73.20 & 77.10 & 93.31 & 93.63 \\
\hline$T_{13}$ : Control & 80.20 & 77.90 & 24.22 & 24.00 & 97.20 & 96.50 & 110.83 & 107.80 & 53.80 & 49.82 & 85.00 & 83.86 \\
\hline $\mathrm{SEm} \pm$ & 1.27 & 0.93 & 0.99 & 1.11 & 1.33 & 1.14 & 1.59 & 1.32 & 2.02 & 1.82 & 0.95 & 1.29 \\
\hline CD at $5 \%$ & 3.82 & 2.81 & 2.99 & 3.34 & 4.02 & 3.45 & 4.78 & 3.98 & 6.08 & & 2.89 & 3.88 \\
\hline
\end{tabular}


Similar findings have also been reported by Naidu et al. (2001) in tomato, Mishra and Tripathi (2011) Gupta and Tripathi (2012), Kumar et al.(2015), Tripathi et al. (2015) and Singh et al. (2015) in strawberry.

The maximum number of branches (32.80 and 34.20) were recorded with application of vermicompost $5 \mathrm{t} / \mathrm{ha}+$ Azotobacter $10 \mathrm{~kg} / \mathrm{ha}+$ PSB $10 \mathrm{~kg} / \mathrm{ha}\left(\mathrm{T}_{11}\right)$ during years $2014-15$ and 2015-16, respectively. The treatment $\mathrm{T}_{5}, \mathrm{~T}_{6}$, $\mathrm{T}_{7}, \mathrm{~T}_{8}, \mathrm{~T}_{9}, \mathrm{~T}_{10}$ and $\mathrm{T}_{12}$ were found at par. While minimum numbers of branches per plant (24.22 and 24.00) were recorded under control $\left(\mathrm{T}_{13}\right)$ during the years $2014-15$ and 2015-16, respectively. The significant and positive increase in number of branches per plant might be due to application of vermicompost, Azotobacter and PSB which resulted helpful improving in nitrogen and phosphorous availability and thereby causing higher protein synthesis resulting in more morphological growth. The results are in conformity with the Kumar et al. (2015) who reported positive effect of vermicompost and PSB on number of branches in strawberry.

All the treatments influenced the days taken to flowering and values obtained were found significant. However, the maximum days taken to flowering (109.5 and 109.7 days) were recorded with application of vermicompost $5 \mathrm{t} / \mathrm{ha}+$ Azotobacter $10 \mathrm{~kg} / \mathrm{ha}+$ PSB $10 \mathrm{~kg} / \mathrm{ha}\left(\mathrm{T}_{11}\right)$ followed by pressmud 10 $\mathrm{t} / \mathrm{ha}+$ Azotobacter $10 \mathrm{~kg} / \mathrm{ha}+$ PSB $10 \mathrm{~kg} / \mathrm{ha}$ $\left(\mathrm{T}_{12}\right)$ during both the years. The minimum days taken to flowering (97.2 and 96.5 days) were observed under control during both the years 2014-15 and 2015-16, respectively. The higher days taken to flowering and due to the vermicompost, Azotobacter and PSB application that play on role in prolonged growth of plants. These results got the support of the finding of Singh et al. (2015) in strawberry who recorded delay to days taken to flowering with vermicompost +
Azotobacter + PSB + AM treatments. The days taken to fruiting increased with the application of various combinations of organic manure and biofertilizers. All the treatment exhibited the increase in days taken to fruiting significantly over the control. However, the maximum days taken to fruiting (126.10 and 128.40 days) were recorded with combined application of vermicompost $5 \mathrm{t} / \mathrm{ha}$ + Azotobacter $10 \mathrm{~kg} / \mathrm{ha}+$ PSB $10 \mathrm{~kg} / \mathrm{ha}\left(\mathrm{T}_{11}\right)$ during both the years 2014-15 and 2015-16, respectively. The minimum days taken to fruiting (110.83 and 107.80 days) obtained during year 2014-15 and 2015-16 respectively under the control $\left(\mathrm{T}_{13}\right)$ The higher days taken to fruiting due to the vermicompost, Azotobacter and PSB application that play on role in prolonged growth of plants which ultimately increased days taken to fruiting. These results close conformity with Singh et al. (2015) in strawberry.

The highest number of flowers per plant (74.82 and 79.20) were recorded with application of vermicompost 5t/ha + Azotobacter $10 \mathrm{~kg} / \mathrm{ha}+\mathrm{PSB} 10 \mathrm{~kg} / \mathrm{ha}\left(\mathrm{T}_{11}\right)$ followed by pressmud $10 \mathrm{t} / \mathrm{ha}+$ Azotobacter $10 \mathrm{~kg} / \mathrm{ha}+\mathrm{PSB} 10 \mathrm{~kg} / \mathrm{ha}\left(\mathrm{T}_{12}\right)$ and FYM 10t/ha + Azotobacter $10 \mathrm{~kg} / \mathrm{ha}+$ PSB $10 \mathrm{~kg} / \mathrm{ha}$ $\left(\mathrm{T}_{10}\right)$ during 2014-15 and 2015-16, respectively. Minimum number of flower per plant (53.80 and 49.82) obtained during both year of experimentation under the control $\left(\mathrm{T}_{13}\right)$. It may possibly be due to the fact that vermicompost and biofertilizers application accelerated the development of inflorescence, leaf numbers in autumn. These results are also in close conformity with the finding of Singh et al. (2015) in strawberry with application of vermicompost + Azotobacter $+\mathrm{PSB}+\mathrm{AM}$ and Mishra and Tripathi (2011) in strawberry with use of Azotobacter $6 \mathrm{~kg} / \mathrm{ha}$. + PSB 6 $\mathrm{kg} / \mathrm{ha}$. All the treatments showed significant increase fruit set. However, the maximum fruit set (93.85 and 94.19 per cent) were 
recorded with use of vermicompost $5 \mathrm{t} / \mathrm{ha}+$ Azotobacter $10 \mathrm{~kg} / \mathrm{ha}+\mathrm{PSB} 10 \mathrm{~kg} / \mathrm{ha}\left(\mathrm{T}_{11}\right)$ followed by pressmud $10 \mathrm{t} / \mathrm{ha}+$ Azotobacter $10 \mathrm{~kg} / \mathrm{ha}+\mathrm{PSB} 10 \mathrm{~kg} / \mathrm{ha}\left(\mathrm{T}_{12}\right)$ and FYM 10 t/ha + Azotobacter $10 \mathrm{~kg} / \mathrm{ha}+$ PSB $10 \mathrm{~kg} / \mathrm{ha}$ ( $\left.\mathrm{T}_{10}\right)$ during the years 2014-15 and 2015-16, respectively. While minimum per cent fruit set ( 85.00 and 83.86 per cent) were recorded in control during both the years of experimentation. It was might be due to vermicompost and biofertilizers application accelerated the development of inflorescence, leaf numbers in autumn, which are positively correlated with number of flowers, number of fruits as well as per cent fruit set. Similar results were also obtained by Singh et al. (2015) and Mishra and Tripathi (2011) in strawberry.

\section{References}

Anonymous (1969). The Wealth of India, (CSIR) Vol. VIII p. 38-40.

Chattopadhyay, T.K. (1996). A Text Book of Pomology. Vol. $2^{\text {nd }}$ Kalyani Publishers, New Delhi.

Gupta, A.K. and Tripathi, V.K. (2012). Efficiency of Azotobacter and vermicompost alone in combination on vegetative growth, flowering and yield of strawberry. cv. Chandler. Progressive Hort. 44(2): 256-261.

Gupta, S.K. and Roy, S.K. (1980). Multipurpose Cape gooseberry. Indian J. Hort, 24 (4): 11.

Hayes, W.B. (1966). Fruit growing in India $3^{\text {rd }}$ revised ed. Kitabistan, Allahabad, pp. 415-416.

Khan, K.F. and Gowder, R.B. (1955). The cape gooseberry-a-remunerative intercrop for orchid in Nilgiri. South Indian Horticulture. 3 (4):104-107.

Kumar,R. and Srivastava, B. K. (2006). Residual effect of integrated nutrient management on growth, yield and yield attributes of tomato. Indian J. of
Hort. 63 (1): 98-100.

Kumar, N.; Singh, H.K. and Mishra P.N. (2015). Impact of organic manures and biofertilizers on growth and quality of strawberry cv. Chandler. Indian Journal of Sci. and Tech. 8(15)1-5.

Legge, A. P. (1974). Notes on the history, cultivation and use of $P$. peruviana L. Journal of Royal Horticultural Society, 99 : 310-314.

Majumdar, B.C and Bose, T.K. (1979). Analysis of Cape gooseberry fruits. Plant Science, 11: 101.

Majumdar, B.C. (1979). Cape gooseberry. The jam of fruit of India. World Crops, 31: 19-23.

Mishra, A.N. and Tripathi, V.K. (2011). Effect of biofertilizers on vegetative growth, Flowering, yield and quality of strawberry. Proceeding of the International Symposium on minor fruit and medicinal plants for health Ecological security (ISMF\&MP), West Bengal India, 211-215.

Morton, J.F. (1987). Fruits of Worm Climates. Creative Resource Centre Inc. Miami., pp. 431- 434.

Naidu, A.K.; Kushwaha, S.S.; Mehta, A.K. and Jain, P.K. (2001). Study of organic, Inorganic and biofertilizers in relation to growth and yield tomato. Research J. JNKVV , 35(1-2)36-37.

Panse, V. G. and Sukhatme, P.V. (1985). Statistical method for agricultural workers, ICAR, New Delhi.

Ramadan, M.F. and Morsel, J.T. (2007). Oil goldenberry (Physalis peruviana L.). A novel fruit source of fat soluble bioactives. INFORM, 51: 130-131.

Sarangi, D.; Sarkar, T.K.; Roy, A.K.; Jana, S.C. and Chattopadhyay, T.K. (1989). Physico-chemical changes during growth of cape gooseberry fruits (Physalis peruviana L.). Progressive Horticulture., 21 (3-4) : 225-228.

Singh, A. K.; Beer, K. and Pal, A.K. (2015). 
Effect of vermicompost and biofertilizers on growth, flowering and yield of strawberry. Annals of Plant and Soil Research. 17(2):196-199.

Tripathi, V.K.; Kumar, S. amd Gupta A. K.
(2015). Influence of Azotobacter and vermicompost on growth, flowering, yield and quality of strawberry cv., Chandler. Indian J. Hort. 72(2):201205.

\section{How to cite this article:}

Shreekant and Ram, D. 2018. Effect of Organic Manures and Biofertilizers on Vegetative Growth and Fruit Set of Cape Gooseberry (Physalis peruviana L.). Int.J.Curr.Microbiol.App.Sci. 7(08): 2772-2778. doi: https://doi.org/10.20546/ijcmas.2018.708.291 